\title{
湿原における微気象と熱の動態
}

\section{北海道大学大学院 高橋英紀*}

\section{I 、はじめに}

湿原を安定的に存在させるために必要なのは, 常 に過剰なほどに供給される水分である，言い替える ならば，水収支のバランスが水分の多い状態で保た れる環境である。このような環境を形成するために は気象・水文・地形・土壤・地質などの条件が整わ なければならない.なかでも気象と水文が最も重要 な役割を演じる、気候が温暖な地域では日射も強く 気温も高いために蒸発散により失われる水分が多く， それを上回るような降水あるいは周辺からの河川水 の流入などが必要であり, それとともにその水を停 滞させておくような洼地あるいは平地・緩斜面がな ければならない、たとえばフロリダ半島の中央部か ら南端に広がる湿地带は豊富な降水とそれを停滞さ せる平坦な地形が湿地帯形成の主要な要因であり, インドネシアのカリマンタン島の広大な湿潤熱帯林 も同様である。一方, 日射が少なく気温も低い高緯 度地方では蒸発散量が少なく, わずかな降水でも過 剩水となり湿原を形成することがある。そこでは水 を停滞させるための窪地や平地が必ずしも必要では なく, ヨーロッパの大西洋沿岸地域などのように, 気温や降水の年変化が少なく常に湿潤な気候下では, 平地には降水による水供給だけで湿原植生が成立す るレイズドボッグ (高層湿原が著しく発達し中央部分 が盛り上がったもの) や山地にはブランケットボッグ (斜面や丘陵の頂部に高層湿原が発達し毛布をかけた状 態にみえるもの）が各地に発達する.

このように, 湿原の特徴として湿原の内部に豊富 な水を内臓していることがまず第一に挙げられる。 しかし，この内蔵している水も必ずしも一定ではな く, 主として降水量の変動に左右される、その変動
愊はその湿原の地形とも関連し，わずかな降水の変 動で地下水位が大きく変動することもある.さらに その湿原が海岸に近く海水による水供給が主体とな る場合には, 熱帯・亜熱帯地域のマングローブ林や 北海道佐呂間湖岸のアッケシソウ群落湿原のように 耐塩性の強い植物からなる湿原となる。

湿原の地表面下では水分が多いために酸索の供給 が少なく，植物遺体などの有機物の分解が遅くなる。 地上部での植物生育が旺盛で土壤への有機物の供給 が分解速度を上回ると土㙵に未分解有機物が堆積す る.泥炭あるいは泥炭土と呼ばれるものである. 湿 原では多くの場合にこの泥炭の堆積が見られ, 生態 学的にも水文・気象学的にも特殊な環境がつくられ る. 北ヨーロッパや日本など高緯度地带に発達する 湿原や熱帯・亜熱帯の内陸部の湿原にはこのタイプ の湿原が多い. 表一 1 に世界各地の泥炭地面積を,

\section{表一 1 世界各地に分布する泥业地の面積}

(10万ha以上, Taylor, 1983)

\begin{tabular}{lc}
\hline 国 & 名 \\
\hline カナダ積 $(\times 1000 \mathrm{ha})$ \\
旧ソ連 & 129,500 \\
フィンランド & 71,500 \\
アメリカ & 10,000 \\
中国 & 7,510 \\
ノールウエイ & 3,480 \\
マレーシア & 3,000 \\
ドイッ & 2,360 \\
イギリス & 1,618 \\
スエーデン & 1,508 \\
ポーランド & 1,500 \\
アイルランド & 1,500 \\
アイスランド & 1,175 \\
\hline & 1,000 \\
\hline
\end{tabular}

*北海道大学大学院地球環境科学研究科 $\overline{0} 060$ 札瀶市北区北 10 条西 5 丁目

Graduate School of Environmental Science, Hokkaido University, N-10 W-5 Kita-ku, Sapporo, 060 Japan 


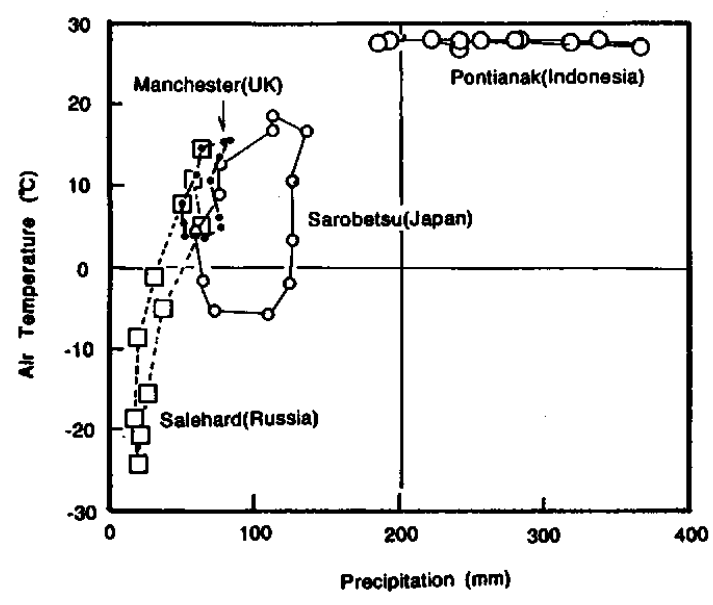

图一1 泥炭の堆楼する湿原が見られる地域のクラ イモグラフ.

図一 1 に泥炭の堆積が見られる地域で最も寒冷な口 シア北部, 最も温暖なインドネシアのカリマンタン, そして北海道のサロベツ湿原のクライモグラフを示 す.なお,ここでは主として泥炭の堆積した湿原を 対象として，そこにおける微気象と熱の動態につい て解説する.

\section{II．湿原の熱収支特性}

湿原における気象現象を理解するためには，湿原 の熱収支特性を知ることがまず必要である，湿原の 熱収支観測の先駆的事例として1961年から10年間に わたって, サロベツ湿原を対象にして北海道開発局 がおこなったサロベツ総合調查特殊気象班の成果が ある(北海道開発局，1972)。サロベツ湿原は天塩川の 支川であるサロベッ川が北西から南へと大きく湾曲 する部分の低地に発達した高層湿原で，30年ほど前 までは春先の融雪出水により毎年のように湛水し, 周辺の農地にも被害を与えていた。 その湾曲部分を 短絡し洪水を防止する目的で放水路が建設されたが, その建設の前後で自然環境・社会環境がどのように 変わるかを追跡調查したのがサロベツ総合調查であ る.

図一2 はサロベツ放水路の近くに設けられた観測 点で，放水路の影響がまだ全くなかった1961年と放 水路が完成し地下水位が低下して乾燥がかなり進ん だ1967年の地表での熱収支各項の比較をしたもので ある. 観測した時期は 7 月上旬と 8 月下旬でやや季 節的な隔たりはあるが 8 月下旬は植物が枯れ始める にはまだ早く, 生物的な活性の程度もほほ同じと見
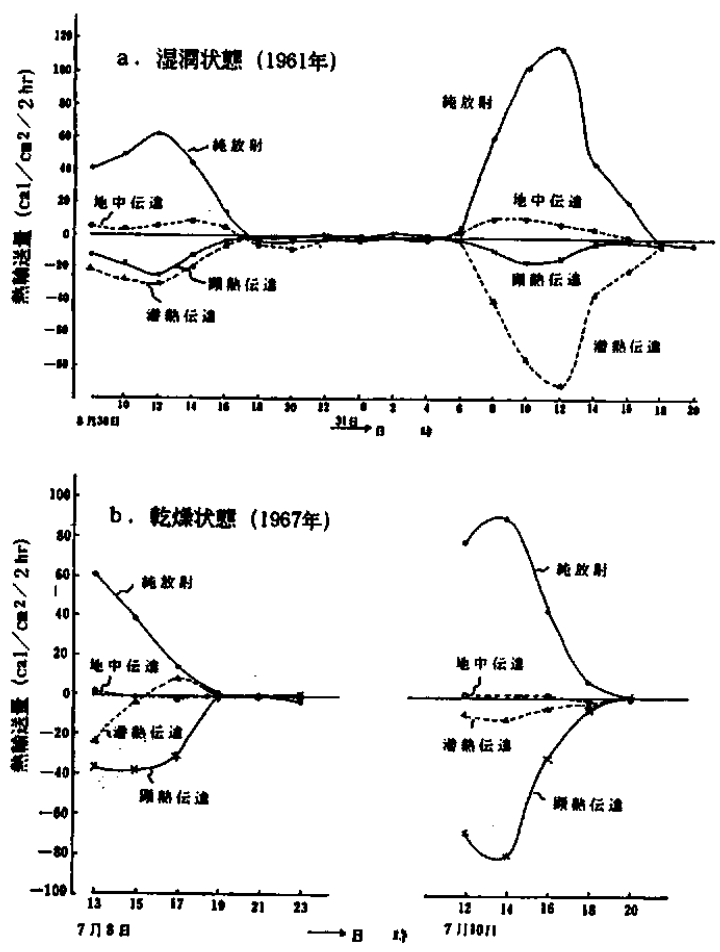

図一2 サロベツ湿原における放水路完成前（湿㵎 状態）と完成後（乾燥状瑟）の地表面勢収 支の比較（北海道開発局，1972）。

られるのと，日中の純放射が双方とも同程度であり， 比較は可能である．湿潤状態の1961年には地表に入 る放射エネルギーのおよそ $80 \%$ が蒸発のエネルギー として消費されているのに対し，乾燥した1967年に は蒝発は $10 \%$ 前後と非常に少なく, 逆に大気が地表 により直接あたためられて熱が伝わるいわゆる影熱 として $90 \%$ 近くが消費されている.

このように, 湿原では乾燥化がすすむと, 地表て の熱収支バランスが大きく変化するが，その最大で 直接の原因は地表をおおう泥炭土壤の熱特性の変化 である. 長期的には乾燥化による植物相の変化にと もなう植物群落構造の変化と, それによって生じる アルベドなどの放射特性の変化, 地表面粗度などの 空気力学的特性の変化, 気孔コンダクタンスなどの 水分生理特性の変化などが原因となる.

\section{III．泥炭土の熱特性}

泥炭土の熱容量は水分含量に大きく依存する。一 般に土塞の比熱は式(1)で表されるが，泥炭土では植 物遺体が主要な構成物質であるから泥炭中の固体成 


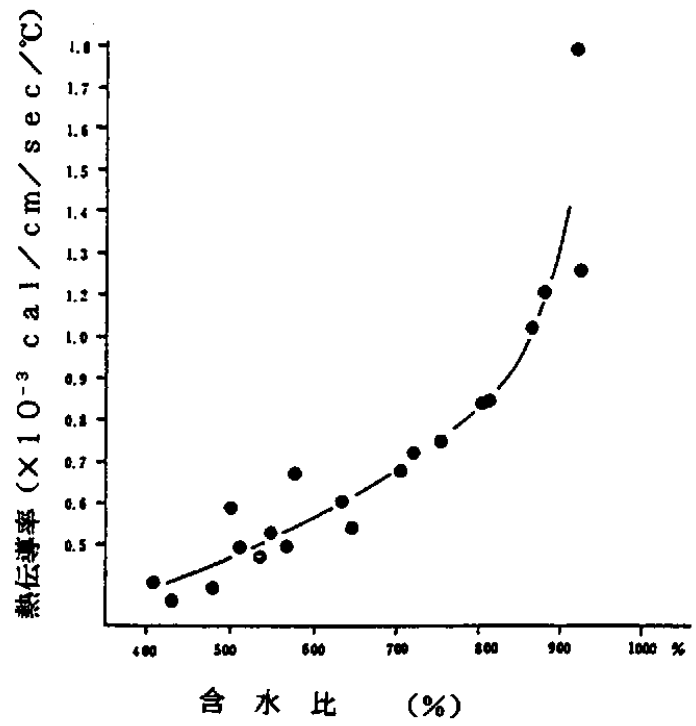

图一３サベツ湿原の高位泥炭土の熱伝等率と土 壤含水比の関係（北海道開発局，1972）
分の重量比はきわめて小さく, サロベツ湿原のよう な高層湿原では乾煤状態で $20 \%$ ，湿潤状態で $5 \%$ 程 度である。釧路湿原のような低層湿原では河川から の土砂の混入が多くなり，固体成分がしめる割合が 多くなるが，それでも鉱物質を主体とする土壤に比 べて水分にたいする依存性は高い。

$$
C_{\text {soil }}=C_{\text {sotid }}(1-w)+C_{\text {water }} \cdot w
$$

ただし， $C_{\text {soill }}, C_{\text {solid }}, C_{\text {water }}$ : 泥炭土全体，固 体成分および水の比熱 $w$ ：含水率

泥炭, 特に高位泥炭は未分解の植物遺体がからま りあった状態になっており，その間隙に水が存在す る. そのため乾燥がす寸むとその豊富な間隙が空気 でおきかわり，断熱材のような性状となってくる． 実際に，アイルランドやスコットランドではかつて 家屋の壁や屋根に断熱材として使用しており，現在 でも観光用として残っているものもある.

図一3 はサロベツ湿原の高位泥炭の熱伝導率と土 㙵含水比との関係を示したものである. 乾燥状態(含 水率 $480 \%$ ）のときの熱伝導率は $0.15 \mathrm{~W} \cdot \mathrm{m}^{-1} \cdot \mathrm{K}^{-1}$ で,

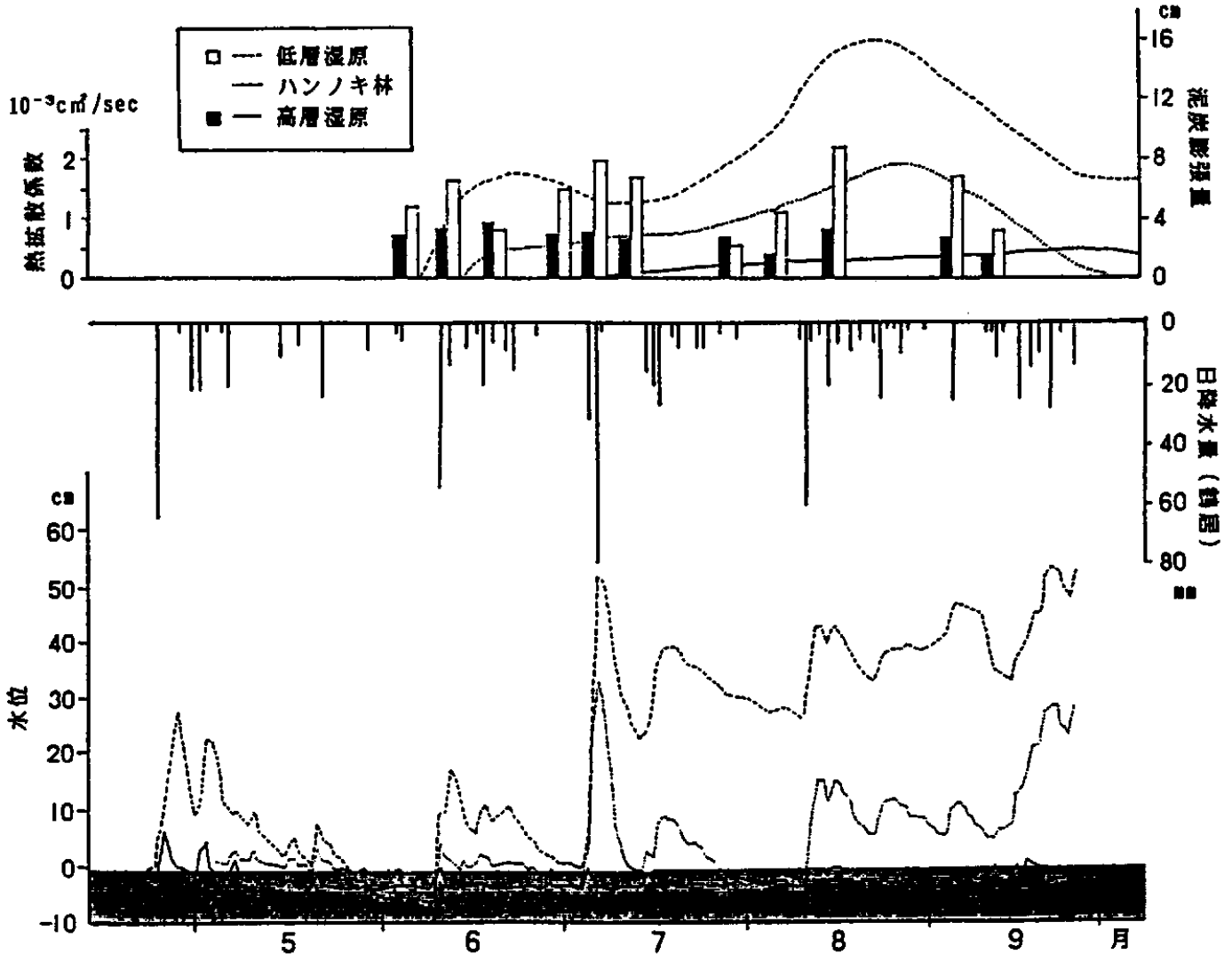

図一４釧路湿原における高層湿原と低庿湿原の土壤熱拡散係数の季節变化（環境庁，1993） 


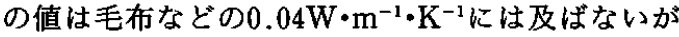
レンガの $0.6 \mathrm{~W} \cdot \mathrm{m}^{-1} \cdot \mathrm{K}^{-1}$ よりもはるかに小さい.

土壤水分の変化による土壌熱伝導率の変化の原因 の一部は熱拡散係数の変化によるものである.図 -4 は，数年前に設立された釧路湿原国立公園の中 央部分にひろがる低層湿原と高層湿原における降水 量と地下水位の変化，および地温変動からもとめた 表層土埕の拡散俰数の季節変動である，地下水位が 高く土砂の混入比率の高い低層湿原では，6 月から 9 月までの観測期間中, 地下水位が低く未分解の植 物遺体が多い高層湿原よりも，ほほ 2 倍前後の高い 値で推移している。

このような泥炭土の特殊な熱的性質が接地気象に 及涩す影響は大きく，次に示すような局地気候にま で変化を及ほしている。

\section{IV . 湿原における地下水位低下が局地気候・ 接地微気象におよほす影暨}

フロリダ半島の南部にあるオケーチョビー湖の南 には幅 $65 \mathrm{~km}$ ，長さ $160 \mathrm{~km}$ の大湿原がひろがっている. エバーグレイズと呼ばれる地域である。この地域で は1910年ころからコケーチョビー湖近くの $2,000 \mathrm{~km}^{2}$ (サロベツ湿原の14倍, 八郎潟干拓地の 8 倍) の広大な 泥炭湿原の排水が行われ農業開発か進められてきた。 ところがこのエバーグレイズ農業地帯では, 周辺地 域に此べて最低気温が $5{ }^{\circ} \mathrm{C}$ 活ど低いことが地域内に 設けられた20ケ所ほどの気象観測所のデータから知 られるようになった。しかし観測点の数が十分でな く低温域の実態が不明であった。

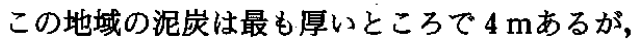
大部分は1.3m以下のであり，サロべツ湿原，釧路湿 原に比べやや薄い泥炭層であると言える。この農業

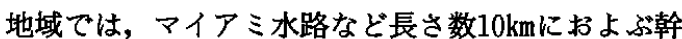
線放水路とそれにつながる大小の用排水路網により 水管理が行われている，この地域で特筆すべきこと は, 農業開発地域に隣接して野生生物のための口ク サハッチー自然保護区を設けられたことである。保 護区の周囲には堤防を設け，オケーチョビー湖や周 辺農地からの排水を逆にポンプアップすることによ り，地下水位の低下を防いでいる，すなわち農業開 発以前の状態が隣接して残されていることにより， 湿原の地下水位低下による局地気候の変化が検証て きることになる.

フロリダ大学のチェン氏ら(Chen, E. et al ., 1979) は気象衛星GOES- 1 号の赤外デー夕を使い, 図一 5
に示したオケーチョビー湖・エバーグレーズ農業地 域・ロクサハッチー自然保護区を含む緯度にして $7^{\circ}$ ，経度で $2^{\circ}$ の地域の夜間の地表面温度を解析し

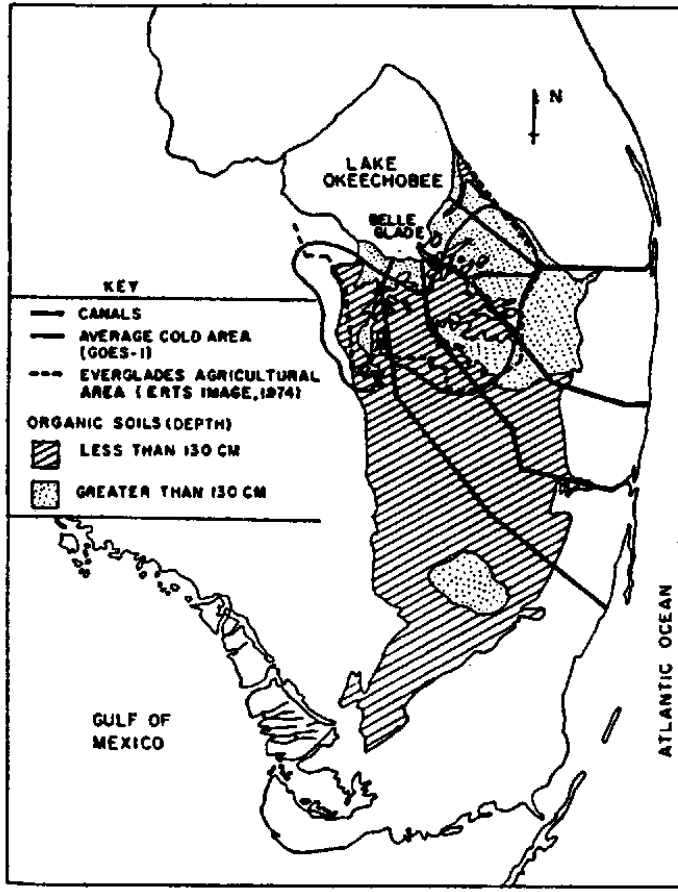

图一5 フロリダ半島とエバーグレイズ農業開発地 区，ロクサハッチー自然保護区の位置 (Chen, E. et al., 1979)
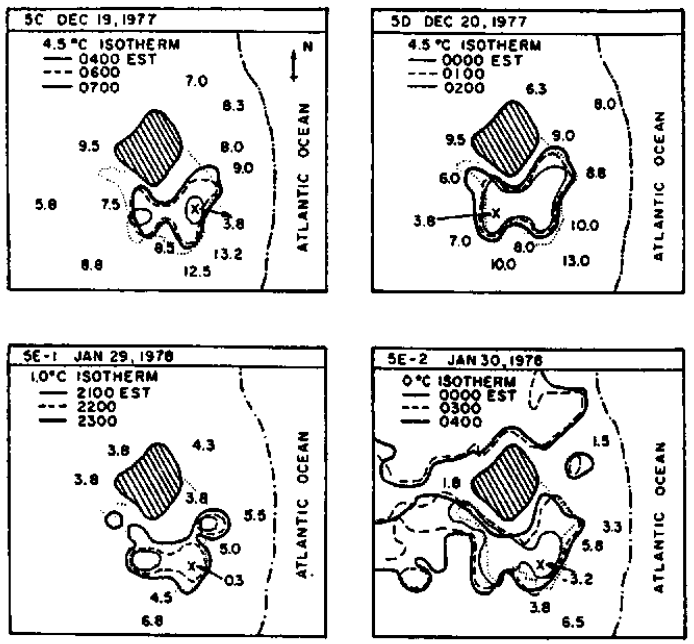

图一６ＧOES-1による1977年12月から1978年 1 月 にかけての地衰面温度解析の例 (Chen, E., 1979) 


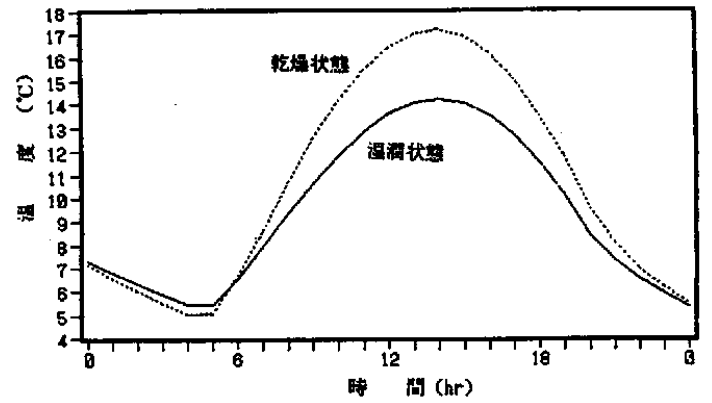

図一7 1 次元非定常モデルによる湿原の乾嬠化が 接地気温におよはす影禹の算定（前田一歩 園財団，1993）

表一2 モデル計算に使用した泥炭土の熱特性 (環境庁, 1993)

\begin{tabular}{|c|c|c|c|}
\hline & & 湿潤状態 & 乾燥状態 \\
\hline 含水比 & $\%$ & 1400 & 480 \\
\hline 熱容量 & $\mathrm{Jm}^{-3} \mathrm{~K}$ & $3.04 \times 10^{3}$ & $1.88 \times 10^{3}$ \\
\hline 熱拡散係数 & $\mathrm{ms}^{-1}$ & $1.1 \times 10^{-5}$ & $0.88 \times 10^{-5}$ \\
\hline 熱伝蓬率 & $\mathrm{Jm}^{-1} \mathrm{~s}^{-1}$ & $\mathrm{~K}^{-1} 0.33$ & 0.16 \\
\hline
\end{tabular}

た結果，図一6に示したように農業開発地域だけが 低温化していく過程が浮き彫りにされた。隣接する 高地下水位の自然保護区とは $9^{\circ} \mathrm{C}$ 以上の温度差と なったのである.

このフロリダ半島でみられた局地気候現象は, 先 に述べたサロベツ湿原でも報告されていた（北海道 開発局, 1972).サロベツ総合調査一般気象班の調査と 解析によると, サロベツ湿原内に設けた気象観測所 の最低気温に放水路完成前の 4 年間と完成後の 4 年 間で明瞭に差が認められ，特に晴天夜間には， 5 月・ 6 月の平均で $0.7^{\circ} \mathrm{C}, 7$ 月・ 8 月の平均で $0.8^{\circ} \mathrm{C}$ ほど 完成後の方が低温であった，地下水位低下が進行す ると日最低気温の低下の傾向はさらに助長される.

サロベツ原野では1977年の春から初夏にかけてき わめて少雨であった。さらに，6月下旬から 7 月上 旬にかけて $0{ }^{\circ} \mathrm{C}$ 近くまで冷え込んだサロベツ湿原で は, 湿原を代表する花であるエゾカンゾウの花芽が 打撃をうけたらしく，ついに花を見ない年となって しまった。これも湿原の乾燥化がもたらした生態系 へのインパクトと言えよう.

湿原に扔ける地下水位低下と地表の乾燥化が接地 気象に抢よ济す影響について, 土裹, 植物群落, 接 地境界層を組み込んだ 1 次元非定常モデルで比較し た結果を見ると(図一7)，6月の釧路湿原での計算

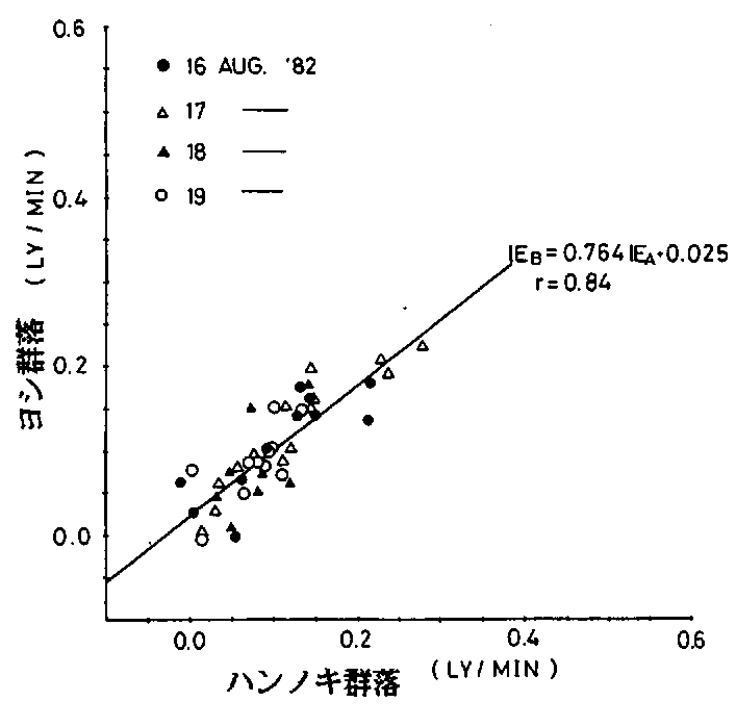

図一8 釧路湿原におけるハンノキ群落とキタヨシ 群落の蒸発散豆の比較 (Takahashi et al, 1984)

例では植物群落の直上にあたる高さ $1.5 \mathrm{~m}$ での最低 気温が $0.5^{\circ} \mathrm{C}$ 低下, 最高気温の $3.0^{\circ} \mathrm{C}$ 上昇するとの 結果が得られている. 計算に使用した土壤の熱特性 を表一 2 に示す。このように湿原の乾燥化は接地微 気象にかなりの影響をおよほしており，世界各地で 行われている湿原の開発あるいは保全の事業におい て十分な検討が必要とされる。

\section{$\mathrm{V}$ 、湿原の植生变化が蒸発散・微気象構造に およはす影翌}

釧路湿原を代表する植物群落はハンノキ林とヨシ 群落である.ミズゴケなどの高層湿原群落もあるが, 全体の面積からみるとあまり大きくはない、釧路湿 原ではハンノキ林の消長が湿原全体の水循環にどの ように影響するかが長い間の論争点であった。しか し, Takahashiら (1984) の報告によると図一8に見 られるごとく，ハンノキ林の方がヨシ群落より $20 \%$ 前後も蒸発散量が多いことが明かとなった。 その原 因として考えられるのは, 蒸発散の主要なエネル ギー源である純放射量の差である. しかし，そこで の実測結果によると両群落での純放射量の差は少な く主要な原因とは言えない. ハンノキ林では群落構 造が高さ $3 \mathrm{~m} \sim 5 \mathrm{~m}$ に分布するハンノキの樹冠とス ゲを主体とする林床植物群落の 2 重構造になってお

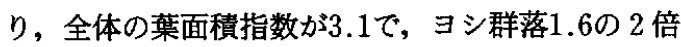
近い值を示している。この葉面積指数の差が土壌表 
面に到達する放射エネルギーの差, 地中伝達熱量の 差となり, 最終的に蒸発散量の差となって現れたこ とが原因の一部と考えられる.しかし，それだけで は両地点の蒸発散量の差を説明するには十分ではな く, 両群落の微気象学的な構造の差, 例えば葉面境 界層あるいは気孔のコクダクタンスの差が影響して いたものと見られる.

植物群落から大気への熱や運動量の拡散は植物群 落の物理的構造, 高さや密度などにより影響される。 それは群落上を吹く風の垂直分布から得られる空気 力学的特街量として表現される. 植物群落上を吹く 風の熱的安定度が中立状態のばあい風速の垂直分布 は式(2)の対数式で表されるが, ここで用いられる地 表面粗度長 $\left(Z_{0}\right)$, 地表面修正量 $(d)$ は植生の高さや密 度によって変わるパラメータであり, 摩擦速度 $\left(U_{*}\right)$ は植物群落上面にかかる風の剪断応力の平方根に比 例する量で接地気層での運動量や物質の拡散にかか わる重要な量である。このU*を使い式(3)でもとめた $r D$ が拡散抵抗と呼ばれ, 運動量や物質の輸送の難易 度の指標として使われる。

$$
u=\frac{U_{*}}{k} \ln \frac{z-d}{z_{0}}
$$

ただし, $u$ : 高さ $z$ で風速, $k$ : カルマン常数

$$
r D=\left(U_{21}-U_{z 2}\right) / U_{*}^{2}
$$

$$
\text { ただし， } U_{21}, U_{z 2}: \text { 高さ } z_{1}, z_{2} \text { での風速 }
$$

表一3に1983年 8 月に観測された釧路湿原におけ るハンノキ林とヨシ群落における空気力学的特徴量 の平均値を示す(環境庁, 1984). ハンノキ林でえられ た $z_{0}=32.6 \mathrm{~cm}$ という值は, 平均樹高 $5 \mathrm{~m}$ 森林とし ては人工林などで得られている值に比べてやや小さ い. また, ヨシ群落の場合も $z_{0}=5.9 \mathrm{~cm}$ という值は, 草丈 $1.2 \mathrm{~m}$ の群落の值としては水田やムギ畑で得ら れている值にくらべやや小さい，いずれの場合も， 湿原内の自然植生では耕地や人工林に比べ, 群落の 密生度が小さいことが原因である。ハンノキ林の拡 散抵抗rDはヨシ群落の $1 / 2$ であり, ハンノキ林の 方が運動量や熱・物質の移動がしやすい群落である ことがわかる。

なお, 高層湿原の $z_{0}$ 值の測定例はサロベツ湿原に あり, 図一9のように $1 \sim 5 \mathrm{~cm}$ で変動しており, 風 速 4〜 $5 \mathrm{~m}$ で最大值をとっている.このように洛が ある風速の付近で最高值を示す現象は水田でも観測 されており, 水田の場合には $2 \mathrm{~m} / \mathrm{s}$ 付近で最高値を 示していたとの報告がある（谷, 1960).

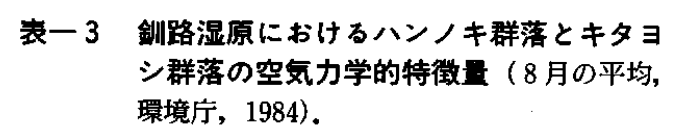

表一3 釧路湿原におけるハンノキ群落とキタョ

\begin{tabular}{|c|c|c|c|c|}
\hline 群落名 & $z_{8}(\mathrm{~cm})$ & $\mathrm{d}(\mathrm{cm})$ & U. $(\mathrm{cm} / \mathrm{s})$ & $\mathrm{rD}(\mathrm{s} / \mathrm{cm})$ \\
\hline ハンノキ & 32.6 & 292 & 44.5 & 0.073 \\
\hline キタヨシ & 5.9 & 54 & 27.8 & 0.135 \\
\hline
\end{tabular}
シ群落の空気力学的特徵量 ( 8 月の平均, 環境额, 1984).

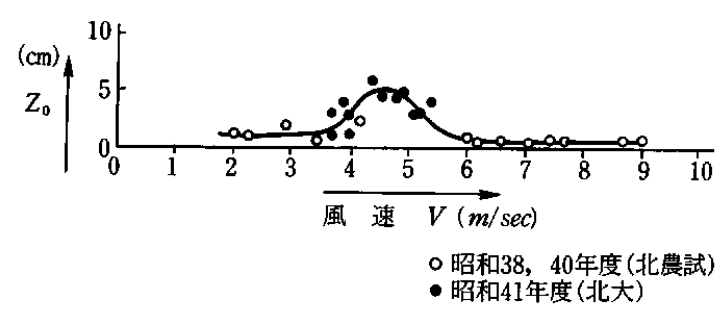

图ー9 サロベッ湿原で観測された風速による地表 面粗度長の変動（横田廉一ら，1967）

\section{V.おわりに}

世界の多くの湿原は土袞層として莫大な泥炭を蓄 えており，その泥炭が内含する有機質に含まれる カーボンの量も莫大であることから, 地球環境の視 点から次第にその重要性が認識されるようになった。 泥炭を内臓する湿原は長い年月をかけて大気中の カーボンを吸収して貯蔵するシンクとして機能して きたことが明かとなり，その無秩序な開発は温暖化 ガスの放出という大きなりスクをもたらすことが知 られるようになった. 現在, 湿原は温暖化ガスのシ ンクあるいはメタンなどのソースと言う新しい視点 から盛んに研究されつつある.

しかし, 湿原植物群落の微気象構造あるいは水分 生理特性に関する研究の集積は, 湿原が残されてい るほとんどの地域が交流奄源の利用できない遠隔地 であること, 群落構成植物が多様でミズゴケなどの ようにかなり特異な形状・生理特性をもつものが含 まれていることなどが原因となって, 現在のところ きわめて不十分である。

近年，エレクトロニクス技術の長足な進歩により， 計測機器が軽量化, 携帯化されつつあり, 湿原内に おける精密な調査・観測も不可能ではなくなってき た. 今後, 多くの研究により湿原に関する様々な情 報が集積されるものと期待される. 


\section{幾考文嗝}

Chen, E., L.H. Allen, JR ., J.F. Barthlic, R.G. Bill, $J_{R}$, , and R.A. Sutherland, 1979: Satellie -Sensed Winter Nocturnal Temperature Patterns of the Everglades Agricultural Area. Jour. Appl. Meteor., 18.992-1002.

横田廉一, 堂腰 純, 堀口郁夫, 高橋英紀, 藤原 忠, 石黒忠三, 1967 ：泥炭原野における放水路の 掘削が周辺の気象要素に及ほす影響. 昭和 41 年度 北海道開発局サロベツ総合調査中間報告書, 気象 部門 (第 2 部). p 63

北海道開発局, 1972 : サロベツ総合調查報告書, 泥 炭地の生態 $\mathrm{V}$, 気象部門. 1-90

環境庁, 1984 : 釧路湿原保全対策緊急調查報告書. $1-252$.
咊境庁自然保護局，1993：湿原生態系保全のための モニタリング手法の確立に関する研究. 前田一歩 園財団，1-439.

Takahashi, H., H. Ishida, S. Takahashi, M. Nakayama, T. Tsujii and Y. Umeda, 1984: Micrometeorology in plant communities in the Kushiro Moor, Hokkaido Japan. Proceeding 7 th Intern. Peat Congress, 493-507.

Taylor, J.A., 1983: The peatlands of Great Britain and Ireland (Ecosystem of the World, 4 B). Elsevier Sci. Publ. Co, 1-46.

梅田安治, 1977 ：咲かなかったサロベツの花. 北海 道自然保護協会誌，16，10-12.

谷 信輝， 1960 : 耕地風の測定結果について。農業 気象, 16, 89-93. 